\title{
At give det løse los
}

\author{
Om Peter Laugesens poesi
}

\author{
STEFAN KJERKEGAARD
}

\begin{abstract}
Ce pourquoi le technocrate est l'ami naturel $d u$ dictateur, ordinateurs et dictature, mais le révolutionnaire vit dans l'écart qui sépare la progression technique et la totalité sociale, $y$ inscrivant son rêve de révolution permanente. Or ce rêve est par lui-même action, réalité, menace effective sur tout ordre établi, et rend possible ce dont il rêve. ${ }^{\mathrm{I}}$
\end{abstract}

I 1972/73 udgiver Gilles Deleuze og Felix Guattari første del, L'Anti-œdipe, af deres store hovedværk $\mathrm{Ca}$ pitalisme et schizophrénie, hvori de forsøger at sprænge den ødipale genealogi inden for psykoanalysen i luften. ${ }^{2}$ Deleuze og Guattaris projekt er intet mindre end at af-ødipalisere det ubevidste, så begærsproduktionen kommer til sin ret. Det vil sige igen at komme på sporet af det ubevidste som en fabrik, hvor begæret anses for at være af konstruktivistisk art; noget, der ikke defineres ud fra en mangel eller et savn, men som en positiv kraft - $i$ stedet for som Freud at stoppe det ind $i$ et antikt teater med Ødipus i hovedrollen. Formålet er at indføre den mere adækvate skizoanalyse frem for den neurotisk funderede psykoanalyse. Psykoanalysens evindelige triangulering (far, mor og mig), og her gør det sikkert ikke noget, hvis ordet triangulering minder læseren om ordet strangulering, skal nedbrydes én gang for alle, dels fordi den er hæmmende, dels fordi trianguleringen reelt set ikke karakteriserer det ubevidstes handlekraft, men derimod ideologiserer det og gør det til et magtinstrument i psykoanalysens tjeneste. Skizoanalysen er derfor anti-autoritær og begæret eller begærsmaskinen altid revolutionær.
Samtidig med, at Deleuze og Guattari sidder i Frankrig og udtænker dette faderopgør med Freud - en befrielse af hans tanker ville de nok selv kalde det - sidder den danske lyriker Peter Laugesen herhjemme og oversætter Antonin Artaud (Artaud $i$ udvalg, 1973). Som bekendt er Artaud tillige et af omdrejningspunkterne i Deleuze og Guattaris bog og ophavsmanden til en sær begrebsgenererende rekvisit i deres tænkning, den organløse krop. Den organløse krop er selve produktionen af begærsproduktionen, det formløse, det uproduktive, sterile, ufødte eller ukonsumerbare (kært barn har mange navne). Kroppen uden organer er Deleuze og Guattaris måde at tale om den mest primitive form for liv, en slags urkraft, og ikke om en projektion, der har noget med nogens egentlige krop at gøre, den er snarere kroppen uden et billede og er en form for væren som ren sansning. Peter Laugesen har formentlig ikke læst Deleuze og Guattari på dette tidspunkt, men desto mere opsigtsvækkende bliver de åbenlyse ligheder, der er at finde imellem Laugesens "poetik" og disses tidlige tænkning. Det første, man lægger mærke til, er begge parters brug af maskiner. Laugesen skriver i Kunsthistorier (1991), at:

Stavelsen er dansen, og linjen er gulvet. Mediet er en STEMME, og det instrument, der transporterer den frem, er en MASKINE./ Det skal tages helt bogstaveligt. For [Charles] Olson er skrivemaskinen et instrument, der gør det muligt at gøre det, Mallarme drømte om: direkte - som med noder - at notere rytmiske kadencer og transskribere sin lytten grafisk til skrift. 3 
Skrivemaskinen sørger for, at et maskinelt element indgår direkte i produktionen af tekst, og dermed er det instrument, som forfatteren spiller på. Den er et materielt udtryk for, at sproget har mistet den umiddelbare forbindelse med refleksionen og selvbevidstheden. $\mathrm{Nu}$ er det ikke længere kun et intellektuelt, men også et æstetisk og sanseformidlet anliggende. 4

Hos Deleuze og Guattari består alting af maskiner, som er forbundet med andre maskiner. Maskinen er for dem en måde at tale om verden på uden at forankre talen i hverken noget subjektivt eller objektivt, men derimod i en fortløbende proces. Det er en måde at tale sig ind til en sammenpasning af de enkelte dele af verden, som er et hele, altså en måde at tale med verden, i stedet for at tale den imod. En sådan levende lydhørhed findes også hos Laugesen, der skriver, at $\mathrm{i}$ en "verdensopfattelse, baseret på halvhed, bliver helhed opfattet som en spaltning", $s$ hvor det er appliceringen af denne spaltning, både han og Deleuze/Guattari forsøger at skrive sig uden om. Halvheden, halvheden ad infinitum, er derimod noget, man må lære at leve med, og disse halvheder passer ikke nødvendigvis sammen $\mathrm{i}$ et forklarligt hele, men er udtryk for verdens paradoksale måde at være på. ${ }^{6}$

\section{Laugesens "poetik"}

Laugesen har aldrig forsøgt sig decideret med en poetik. Tættest på kommer han visse steder i Kunsthistorier. På den anden side skinner de poetologiske overvejelser stort set altid igennem og lader sig automatisk indskrive i værket. Fx finder man disse $\mathrm{i}$ samlingen Anarkotika 1975 (s. 140):

JEG VED ikke hvad jeg arbejder med -/ ikke som helhed -/ i selve processen prøver jeg/ at afklare hvad der sker -/ jeg er ikke ude på at interessere nogen -/ stoffet er poesien som den altid er $-/$ ordene er de samme -/. sætningerne er ikke nogen andre -/ elementerne er ikke forandrede -/ sammenhængene er ikke nye -/ jeg kan ikke gå tilbage til ting jeg har lavet tidligere $-/$ de er færdige -/ tempoet vokser -/ (...) vandreren må beslutsomt finde vejen hjem i gennemtrængende/ blidhed -/ familjen -/ og vi er en klan -/ af præster og magikere -/ analyse af de dæmoniske ting -/ de privates tilfredsstillelser -/ sansernes tyveri -/ der er sikkerhed -/ kun ordenes tomhed
-/ kun sprogets maskine -/ skriften søger huller i sprogets mur -/ se mor nul huller -/ poesiens stregspil -/ håndbold er i dag præget af det brutale forsvar -/ billedet er det samme i alle systemer - / dada - surrealister - lettrister -/ fluxus - buddha -/ zen - teori -/ baudelaire - rimbaud - munch -/ jesus - konceptkunst -/ beethoven - politi - rock -/ marx - mozart - anarki - kapital -/ korruption - / åbne sanser -/ gennemsyret af angst -/ lagt åben for alle indflydelser -/ (..) vi er sammen / det store sorte kunstnerhul -/ det store sorte ejendomshul -/ som et eller andet sted dybt ned i sproget udløser de samme /hårde ord -/ hvis betydning er deres åbenbare vanvittige betydningsløshed - / (...) stof der skriger over kolossale afstande -/ endeløse uforklarlige rum uden kontur -/ uden størrelse -/ stoffet er der -/ den eneste måde jeg kan arbejde på er materielt at konstatere / tegnene -/ tegne dem -/ tegnene er det mindste sted hvor ydre og indre billeder mødes -/ tingen kommer fra arbejdet -/ arbejdet kommer fra tegnene -/ når arbejdet er en maskine er kroppen en maskine -/ sindet er maskinelt og verden er en maskine -/ orden er materiel -/ hvis poesien placeres nogen andre steder $-/$ i sindet eller $i$ verden -/ blir resultatet krig og ødelæggelse -/ kroppen - hånden materialet - (tegnene) -/ det er der -/ det er ikke poetisk materialisme -/ men materiel poesi -/ det er alt eller intet -/ det er klart -

Teksten hører muligvis ikke til Laugesens stærkeste, det gør de poetologiske digte sjældent, men den fungerer udmærket $\mathrm{i}$ denne artikels tjeneste, dvs. til at fremhæve en række karakteristika i forfatterskabet i forhold til Deleuzes og Guattaris litteraturfilosofi. Digtet er nærmest som et selvinterview, og til forskel fra poetikken som genre giver Laugesen her køb på ethvert overblik fra starten. Jeget ved ikke, hvad det arbejder med, i hvert fald ikke som helhed. I stedet søges en refleksion, der er på højde med selve processen, altså får man en poetik i digtform, og det gør man altid "kun" hos Laugesen. Det er et bevidst fravalg af overblik, netop fordi overblikket $i$ sig selv er en ideologisering og dermed en tilraning af magt, hvis man taler med Deleuze og Guattaris retorik fra halvfjerdserne. De indleder deres antiØdipusbog med at omtale Lenz' vandringer, som man finder dem hos Georg Büchner, og sådan en vandringsmand er jeget $\mathrm{i}$ Laugesens digt også. Et jeg, der ikke kan gå tilbage, men som altid er på far- 
ten, fremadskuende og revolutionært7 i sprogets, skriftens og syntaksens maskine. Måske er der tale

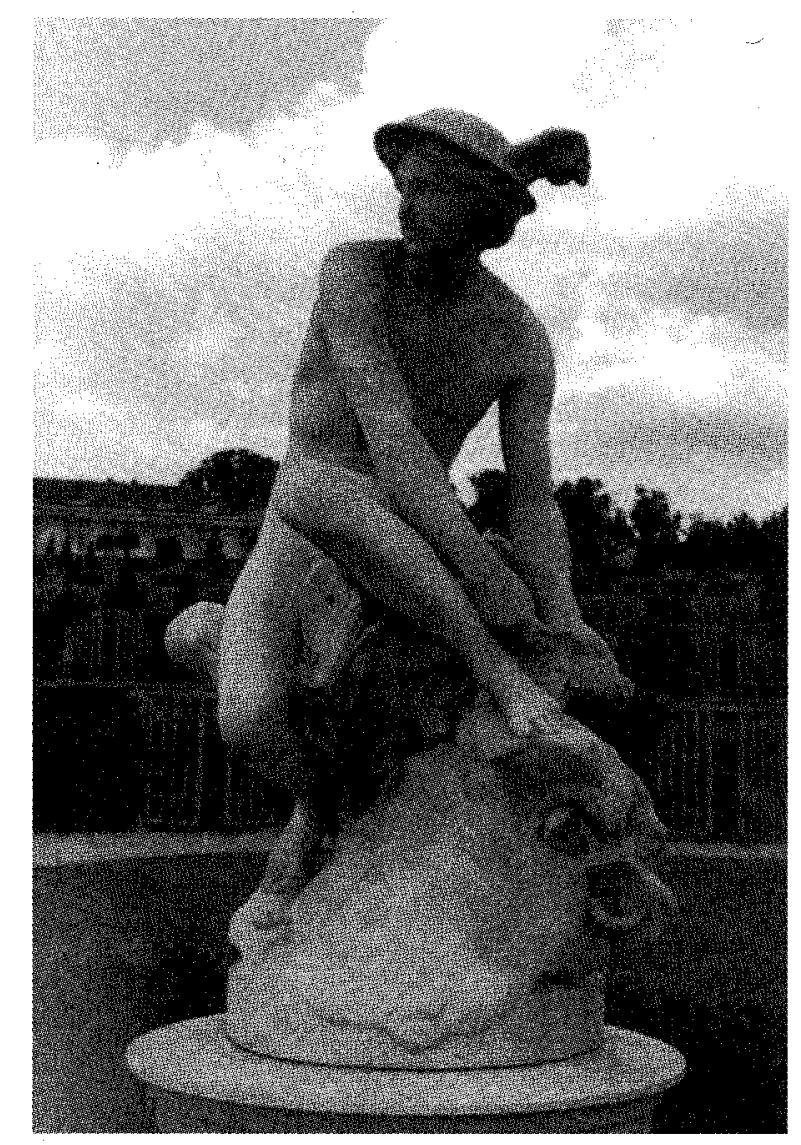

Hermes i Potsdam

om et glemsomt, men bestemt ikke et naivt, uskyldigt eller for den sags skyld romantisk jeg, som man ser: Først $i$ verset "skriften søger huller $i$ sprogets mur”, som er en sætning, der emmer af hul skriftpatos, og følgelig fra starten af er for meget og derfor må dekonstrueres, dernæst $i$ det følgende vers "se mor nul huller". Hullerne i sprogets mur ødipaliseres, men det er dybt ironisk. For det første er de der ikke, når moren kigger, for det andet er der rent faktisk et hul i sprogets mur. Udskiftningen af vokalen $\mathrm{u}$ med $\mathrm{o}$ er et (skriftens) billede på dette hul, men altså et hul, der fører lige lukt ind i en grum ødipalisering, som er poesiens stregspil (sprogets mur/mor). ${ }^{8}$ Her bør man muligvis ikke kalde Laugesens ordspil ironisk, men snarere fuldstændig fladt og humoristisk; i hvert fald hvis man sammenholder det med Deleuzes definition af humor i Logique $d u$ sens (1969). Humoren er nemlig overfladens spil, dens med-udstrækning af meningen med nonsens; her $i$ form af poesiens streg- og ordspil. Ironien derimod involverer altid et subjekt eller en person. Den klassiske ironi forbliver dermed en med-udstrækning af væren og af individet inden for en repræsenterende verden, men et sådant klassisk forstået, $\mathrm{i}$ betydningen filosofisk, individ finder man aldrig hos Laugesen. Jeget kommer nemlig først til sammen med sproget. Med-uds rakningen gælder derfor $\mathrm{i}$ første omgang sproget, hvor Laugesen så bare kalder sin form for nonsens for vrøvl, og én af de måder, Laugesen helt bevidst forsøger at vrøvle på, er ved at rime, hvilket jeg vender tilbage til.

Efter det omtalte ordspil på mur/mor vender jeget i digtet sig, via associationen stregspil til håndbold, imod det brutale forsvar som man kan genfinde $i$ alle systemer, dvs. også det system som jeget selv lige har været involveret $i$, dvs. det psykoanalytiske, samfundsmæssige og lingvistiske. Den eneste måde at modarbejde systemerne på er at lade sig begrave $i$ hullerne "dybt nede i sproget" for dér at håbe på at udløse "hårde ord -/ hvis betydning er deres åbenbare vanvittige betydningsløshed". Det er sådan en materiel poesi, der skitseres her. Poesien hører til i stoffet/materialet og hverken i sindet eller verden, hvor den kun vil skabe krig og ødelæggelse. I materialet kan kolossale afstande bringes sammen $i$ et poesiens revolutionære skrig. Stoffet/materialet er så at sige den eneste gardering imod en egentlig ideologisering af poesien, og vejen over materialet er svaret på, hvordan man finder huller i sprogets mur, uden hele tiden at løbe panden imod sprogets mor, dvs. det store stygge modersmål.

\section{Incipit, begaret er frit}

At begære er som at tegne i rummet, siger Deleuze et sted, 9 og sådan er det også i Laugesens lyrik, der hellere tegner tegnene frem for at sige eller skrive dem. Begæret skal sættes frit i sprogets materiale som en positiv kraft frem for at blive hængende i en freudiansk triangulering. Muligvis finder man derfor påfaldende mange sætninger hos Laugesen, der be- 
gynder med incipit (latinsk betegnelse for "her begynder") som "det regner", "det er", "det foregår", "det trækker" etc. Brugen af incipit (“ça”) er desuden karakteristisk for L'Anti-œdipes begyndelseslinjer. Incipit slører udsigelsespositionen, gør den mangetydig og flerstemmig på én gang. ${ }^{10}$ Sproget virker, om digteren og digtet vil det eller ej, hvilket peger i retning af en helt anden vitalitet end dén, psykoanalysen har en tendens til at drive på flugt. Men det er en vitalitet, som bliver til mellem det, sproget har at tilbyde os, og det som vi har at tilbyde sproget, et sted og en evig positionering mellem et mumleri og et modersmål; hvilket gør inspirationen til en mumlende idiot, som det hedder $\mathrm{i}$ et digt fra $P O W$ (1984), hvor mumleriet handler om sprogets underminerende effekt (nonsens, vrøvl osv.), mens modersmålet handler om det modsatte, dvs. det ideologiserende. Sprogets materialitet, dvs. at det først og fremmest kan og skal sanses, dets sens, hvis man skal sige det med Deleuze, tillader, at en sådan positionering kan finde sted. Som der står i Plettede plusfours (1993, s. 56):

Lyt ved nøglehuller når de mumler for sig selv om natten grebne af et eller andet de ikke kan forklare, de folk der ved hvad de taler om og at der ikke er noget at sige.

Selv de folk, der ved, hvad de taler om, kan gribes $i$ at vrøvle og mumle et sprog, hvor denne viden er ekskluderet. Enhver tro på en fuldmagt over sproget er naiv. Den viden rummer digtet her endog selv, idet den sidste sætning får lov til at svæve uafgørligt, som om digtet passer på med ikke at komme for godt i gang! Det skulle nødig vide alt for meget om det, det taler om, og dermed lyde som de folk dér - dvs. de folk, der ved, hvad de taler om, og ved, at der ikke er noget at sige. Her spejler digtet forfatteren selv, der jo netop har sagt dét utallige gange. Det kan digtet gøre, fordi det er tænkt samtidig med, at det er skrevet, men det ved så at sige ikke noget $\mathrm{i}$ forvejen. Distributionen af viden/magt/ erindring og ikke-viden/afinagt/glemsel er fordelt sådan, at digtet overhovedet kan finde sted. En mu- lig formel for Laugesens digte kan derfor formuleres således: For at digtene kan opstå, må den forrige linje som følge heraf glemmes, men huskes alligevel: Glemmes som den var, og huskes som den ikke er. Det er skriften som begivenhed, der skal iværksætte en sådan formel for vrøvl, som igen har mumleriet, dvs. den potentielle meningsdannelse eller sprogets retning (sens) som sit udgangspunkt. Formlen gælder fra en enkelt linje til en hel digtsamling, og den udspringer af Laugesens affinitet til den fartglade poesi, eksempelvis beatdigtningen, hvor hver stok og sten muligvis bliver talt med, men lige så hurtigt glemt igen. Hvis graden af langsomhed er ligefrem proportional med erindringens intensitet, så er graden af hurtighed ligefrem proportional med glemslens intensitet, ${ }^{\mathrm{II}}$ og hurtigheden eller farten er et særdeles vigtigt element i Laugesens poesi.

Men Laugesens rødder $\mathrm{i}$ beatgenerationen er langtfra de eneste, man kan grave op, for de rødder, der er at finde, udgør snarere et rhizom eller rodnet af litteraturhistoriske forbindelser. Man ser det eksempelvis i efterordet til oversættelsen af Novalis' Hymner til natten (After Hand 1998), hvor Laugesen superkort skitserer en "drømmenes moderne litteraturhistorie” via Novalis, Rimbaud og Jack Kerouac. Efterfølgende skriver han:

Det var vel nok en dejlig litteraturhistorie. Med berusede galninge som vejvisere i det moderne vildnis. En hovedstrøm afvildveje, en lysende sti af mørke. (s. 31)

Mange litterater vil vægre sig ved at udvikle denne type litteraturhistorie mere præcist; alligevel fornemmer man en anden og mere mulighedsbetinget forbindelse imellem de meget forskellige forfattere, der bl.a. har ungdomsværkerne til fælles, som kunne tilføje den halvdøde disciplin en ny vitalitet.

\section{lkke at vare eller at vare undervejs}

Det er bl.a. ad ovennævnte veje, at Laugesen forsøger at styre og ikke at styre sin lyrik fra midten af halvfjerdserne og frem; en vej, der til forveksling ligner den, der bliver formuleret på samme tid af Deleuze og Guattari. Nuvel, Laugesens poesi er muligvis ikke en form for skizoanalyse, men man kan 
tale om en konstant skitsering af et transpositionelt subjekt, der til en vis grad er underlagt sprogets materielle styring, hvilket måske kommer stærkest til udtryk i Katatonien fra 1970. Personligheden som sådan bliver aldrig ( $i$ hvert fald ikke $i$ begyndelsen af forfatterskabet) investeret i projektet, der i langt højere grad handler om at finde en stil og et sprog, hvor jeget opstår som en effekt af disse. Man taler altid til, men ikke fra, som der står i Når engle bøvser jazz (1998, s. 68). Laugesen formulerer noget lignende tidligere i Hamr \& Hak (1977, s. 69):

det kan aldrig blive et spørgsmål om andet end at være til rådighed for det som ikke på anden måde har nogen væren

Der er ingen personlighed på spil i det

jeg forjages og optræder nu kun som ord

der kan ikke være andet end fuldkommen frihed

og det må fortælles af alle til alle

der blir sørget for os alle sammen

ingen andre virkeligheder er virkelig

det er sådan det er

Budskabet, at der ikke er noget, må fortælles af alle til alle. En fuldkommen frihed kan kun komme på tale i det øjeblik, at intet er på spil. Man stiller sig til rådighed for sproget, lader det tale igennem sig på den måde, der virker og virker mest hensigtsmæssig på det givne tidspunkt og sted. Nogle gange er Laugesens digtsamlinger derfor bedre end andre gange, selvom digteren næppe vil indrømme det. Et eller andet sætter teksterne i gang, der skal være et drive, og denne energi, som kun overordnet set kan være den samme, er i sin grund- og rastløshed altid forskellig (igen om Laugesen vil det eller ej). Noget driver digtene af sted, de tager på stop i det uendelige; teksterne er altid undervejs. Ofte indskrives dette "undervejs" i digtet, nogle gange helt konkret som når man i Grassinan Cantos (2002) pludselig finder en indkøbsseddel direkte malet ned over digtet. Andre gange sker indskrivningen af et sådant "undervejs" mere indirekte, $\mathrm{fx}$ når Laugesens tekster speedes op af rim og remser, eller bare det der ligner:
Det er vådt, råt vejr

og rødbær strutter

flot $\mathrm{i}$ hegn

langs med vejen.

Det er godt,

at så små

tegn på liv

kan ses

i det grå.

(Vindens tunge, I986, s. 92)

Rimene vådt/råt/flot/godt, hegn/vejen/tegn, små/ grå dikterer digtets tempo, selvom ingen af dem fungerer perfekt, ikke engang det rim der på papiret ser perfekt ud (små/grå). Det er enjambementet, som både foregiver og ødelægger dette rim, idet de sidste fire vers syntaktisk tilhører den samme (led)sætning, men digtet får, rent lydligt, lov til at stå åbent som små tegn på liv i det grå og i en fortumlet afslutning. ${ }^{12}$

Laugesens rim er sjældent særlig skønne, de er snarere og paradoksalt nok uforsonlige og sjove ${ }^{13}$, men det er, fordi sprogmaskinen arbejder, som den gør - med hamr og hak kunne man sige. Man hører maskinens aftryk i sproget, hvorfor rimene ofte bliver maskinelle som i digtet ovenfor. At de er maskinelle, skal ikke opfattes som en kritik, eller som om Laugesens digte skulle være urytmiske, tværtimod! Laugesens digtning er spækket med rytme, der bærer sproget og giver digtene et specielt præg og en helt særegen frasering. Når jeg her vælger at bruge ordet maskinelt, er det $\mathrm{i}$ en deleuziansk betydning, som noget, der ligger imellem det organiske og det mekaniske. Laugesens rim er et forsøg på at indkredse sprogets maskine, dets skelet og fundamentalhed. Rimene bliver fjollede som børnerim og remser, men det er kun, fordi rim og remser har fat i noget konstituerende for sproget; $\mathrm{fx}$ at det lettere læres ved hjælp af rytme, diktion m.m. frem for ved 
hjælp af betydning og indhold. Sproget har så at sige en retning eller et sigte, før det har et egentligt indhold. Rim er med til at give sproget en retning, før det selv ved af det. For Laugesen er rimet derfor revolutionært $i$ en mikrokosmisk forstand. Revolutionen făr lov til at operere indefra, den iværksættes af sproget i sproget og forbliver immanent. Rim er ikke noget, der skal få digtet til at falde i stilheden på en harmonisk måde, som Dante skriver. ${ }^{14}$ Rim skal derimod få digtet til at falde på halen og aftvinge det en retning, det ikke havde i forvejen. Det er ikke de sørgelige rester af en oprindelig orden, men et instrument til at tvinge sproget fremad, en slags evindelige vejstriber midt $i$ vildnisset. Rim er sprogets egen donation af vrøvl og nonsens, dets med-udstrækning af meningen, ligesom ordspillet og humoren i øvrigt også er det. Man skriver altid i forlængelse af noget andet, og det vigtige er ikke, hvor man begynder, men at man begynder, og at der er fart på undervejs.

\section{Laugesen $i$ verdenskoret}

Laugesens skrivemåde bliver dermed jazzet og improviserende. Betydningen sker med henblik på det kommende, hvilket har forvandlet ham til en oplæsningskonge i løbet af halvfemserne og frem til i dag. Denne forvandling, som egentlig ikke er en forvandling, men en naturlig konsekvens af projektet (at springe ud i stilen og dermed i fraseringen, tonen og åndedrættet), skyldes desuden at skrivemåden har affinitet til rap og hiphop (han skriver et digt med navnet "Hiphop" i Nattur, 1989). Omvendt har den yngre generation muligvis opdaget Laugesen af samme grund. Opdagelsen har derudover to andre væsentlige årsager, dels Lars Bukdahls ansættelse på Weekendavisen og i kølvandet på denne en voldsom reklame, dels at beatgenerationen fik en mindre renæssance i løbet af I990'erne, som var det første årti, hvor jordomrejsen blev en obligatorisk del af unges CV og livsforløb. Den tendens rækker dog ud over den opblomstring, som beatgenerationen blev udsat for i Danmark. Man kunne med Jacques Rancière sige, at de unges revolutionære trang fandt sig et konkret udtryk i rejsen, og rejsen har altid været et indbygget element i Laugesens digtning.
Generelt så verden ikke mere så faretruende ud, efter at muren var brudt sammen i '89, og derfor kunne Laugesens indbyggede revolution, den konstante om- og opbrydning, finde konkrete lighedstræk $\mathrm{i}$ tiden.

I Laugesens digtning har verden fra starten af været faretruende eller måske snarere vital, for selvom der i Nattur (1989) står, at "Fuglene synger aldrig/ uden grund”, så melder verden sig almindeligvis uden en sådan grund. Digterjeget forsøger da at melde sig ind i denne verdens tilfældige kor ved at kvidre med på den evige gentagelse og ved bare at være til og skrive det, der skal shrives, og at finde ud af, hvorfor den har det med at mase sig sådan på uden egentlig at ville noget bestemt, nøjagtig som det sker med skriften:

\section{DIGT}

det der betyder noget og som tiden

helst skulle bruges til. Det

er

næsten aldrig det, der ligger lige

for,

når dagen ruller sig $\mathrm{ud}$.

Så

er det, at man må finde en form

der,

tilfældigt og alligevel (måske)

ubønhørligt (derfor),

får

det

produceret. En helt enkel maskine.

Her.

Okay, så kom det derhen.

Det er ikke, fordi der ikke er noget,

eller for meget,

at

sige. Men fordi selve det at skrive

finder

selv.

(Indianer Joes vandskål, 1990)

Den besynderlige afslutning ser ved første øjekast ud til at mangle et "vej" som i "finder vej selv" eller "fin- 
der selv vej”, men vejen er i mere end en forstand indskrevet og medskrivende $\mathrm{i}$ forvejen, den behøver ikke en eksplicitering, idet den allerede er at finde som hjulspind gennem skrift- og lydbilledet ("selve det at skrive/finder/selv"). Som Laugesen skriver i Deadlines (1994, s. 26): “Jeg er ikke sanger det er en anden/ maskine der pisker blodet til skum/ med hjul af syntaks i fonemisk snurren". Digtene forsøger at indgå enten som hele tandhjul eller bare spærhager i en slags verdensrytmisk maskine, der er vilkårlig og uberegnelig, men som præcis sådan leverer nødvendighed. I Deadlines $\mathrm{fx}$ er det markant, hvordan bogen begynder med noget, der ligner et langdigt, som skyder løs på hvad som helst fra storpolitik til gråspurve, for derefter at udspalte sig mere og mere i enkelte digte, som om det er den vej, digtene og ordene finder (af) sig selv. Cirka halvvejs inde $\mathrm{i}$ bogen dukker så det første "normale" digt op med titel og det hele. Digtet hedder "Budgie", der betyder undulat. Digtenes forsøg på at kvidre naturligt med i verdenskoret mislykkes og afvigeren stemples som undulat, en nomade blandt de ellers så danske gråspurve, solsorte, mejser osv. Ved læsningen af en enkelt strofe kan man få en fornemmelse af, hvordan digtet vrænger sig igennem med udstødte og kunstige ord:

Anna har sin banana

men jeg er en undulat

og henne på Copacabana

så jeg en mark med salat.

(Deadlines, s. 52)

At være undervejs kræver et opbrud, ja det kræver et brud $i$ det hele taget, for det bevidst naive og paradoksale verdensrytmeprojekt kan ikke fortsætte $i$ al evighed. Som der står et andet sted i Deadlines (s. 35): "Jeg gør som altid/ stoler på tilfældet/ som er min død". Tilfældet er abrupt, men det er en abrupthed, som tvinger digtene til at vare på beatet, hvor og hvad det så end måtte være. Der er ikke tale om en blind tillid til tilfældet, men om en ironisk forsoning, en slags affirmation af tilfældigheden der ender $\mathrm{i}$ humor, som når to ord rimer på hinanden, uden at de af den grund betyder det samme. Her finder man endnu en grund til, at der dukker rim op hist og pist hos Laugesen. Rimet peger på -den nødvendige tilfældighed, hvor selve udrykket (dvs. retningen eller sigtet) fungerer tvingende $i$ forhold til betydningen, der er vilkårlig. Med andre og lidt flotte ord kan man sige, at Laugesens digte forsøger at rime på verden, mere for at indgå $\mathrm{i}$ tidens tandhjul end for at forskønne den.

At stole på tilfældet er ensbetydende med en lytten efter som i jazzmusikken, hvor det at lytte il de andre betyder alt for den præstation, man leverer. I samme forbindelse kan man sige, at pausen eller bruddet måske er det sted, hvor selv de mest rytmiske kan udfolde deres rytmiskhed. Det er her, sprogets begivenhed finder sted. Deleuze og Guattari definerer maskinen som et system af brud og sådan fungerer sprogmaskinen også i Laugesens poesi. Hver associative strom må betragtes som noget ideelt, i hvilken maskinen iværksætter sine brud. At digtene i Deadlines ender i sådanne brud, dvs. som "rigtige" digte, viser bare, hvorfor digtene, alle digte, med tiden er kommet til at se ud, som de gør, der er tale om et helt overordnet rytmisk princip, som selv Laugesens evindeligt begyndende sprogmaskine må bøje sig for. Digte er nemlig noget, der slutter ufrivilligt, som bl.a. den italienske tænker Giorgio Agamben har peget på. is De lukker sansningen inde $i$ et finalt element, selvom sansningen i princippet fortsætter i det uendelige udenfor, men digtet bevarer $\mathrm{i}$ bruddet sine sansningers bevægelse, rytme og frasering, som alle kan bringes i oprør ved naste læsning. For den første læsning er selve skriveakten. At skrive og læse bliver derfor under ét at sanse for Laugesen, men at formidle denne sansning til andre kræver et brud, og at sproget, bogstaveligt talt, får lov til at finde sted.

\section{Tre måder $i$ Laugesens digtning}

Deleuze og Guattari har i deres bog travlt med at konstatere, at begærsmaskinen ikke er en metafor ${ }^{16}$, men er det, som bryder, og som bliver brudt af tre måder, man forsøgsvist kunne overføre til Laugesens poesi: 1) den konnektive syntese, 2) den disjunktive syntese og 3) den konjunktive syntese. Den konnektive syntese angår en (og...og)-konstruktion. Her kunne man applicere Laugesens vers, der ofte er uden an- 
givelse af pauserende tegn, men altid kværnende derudaf og tit meget korte. Jævnligt finder man endda et konkret "og" i begyndelsen af dem. Deleuze og Guattari taler også om en produktionsproduktion, som har med libido at gøre.

Den disjunktive syntese har en anden konstruktion (eller...eller) og tilknyttes en registreringsproduktion, som mobiliserer en tingenes særlige livskraft (Numen) i form af løsrivelsesenergi. Det er en sådan produktion, der sørger for at indskrive et "undervejs" i Laugesens poesi, og den er altid skitserende og katalogiserende. Løsrivelsesenergien gør, at alting konstant begynder på ny (og på nu!). I Katatonien (s. 69) står der således meget sigende, at teksten "er afstanden mellem det sted hvor den begynder og det sted hvor den ikke begynder”. Derfor virker digtene og digtsamlingerne ufærdige, men den færdighed, man anvender som målestok, indgår ikke som et egentligt mål for digtene. Hvis digtene har et mål, er det ikke at have noget, for om muligt skal alting med; sansningen hører jo netop aldrig op. I den forstand er Laugesens poesi meget tættere på en egentlig praksis end fx Per Højholts, der et eller andet sted, hvor god dennes poesi end måtte være, emmer af både teori og ideologisering. Ifølge Laugesen bliver udtrykket nemlig ikke mere evigtgyldigt ved, at man fjerner noget fra forfatterskabet og derved destillerer udtrykket, tværtimod risikerer man, at et enkelt tandhjul $i$ maskinen forsvinder og får motoren til at bryde helt sammen. Et sådan sammenbrud er tæt på at ske i Kragetceer (1995), men det er et sammenbrud, som resulterer i mere "rigtige" (i betydningen autonome) digte, hvor erindringen trænger sig på:

Dagens og nattens rytme

er sprængt af vrede og sorg.

Året er ikke et år

men et kortsluttet øjeblik.

Alting er under flytning,

og ingen kan vide, om det

vil finde sig selv

på et andet sted.

Jeg ville så gerne kunne

sætte mig ved mit bord og arbejde noget igennem,

der ikke er tom sensation

og meningsløse signaler,

men alting skal gå så hurtigt,

og tiden er ude af hak

med de drivende hjul.

Her rammes digteren af sin egen fart, og øjeblikket kortslutter. Måske fordi året omkring Kragetcer bød på moderens død, der beskrives flere gange i samlingen. Et dødsfald kræver en erindringsakt, men det er svært at få det til at passe ind i maskineriet. Alligevel er digtet, og specielt som digt, meget vellykket. Det atypiske ved det er så, at Laugesens nomadiske tilgang til lyrikken ikke vinder indpas. Digtet standser nærmest op på en måde, som jeget ikke kan finde ud af, fordi det normalt altid er på farten. Jegets ønske om en gennemarbejdelse virker her paradoksalt set i lyset af digtet selv, der virker særdeles gennemarbejdet. Jegets ønske er allerede gået $\mathrm{i}$ opfyldelse. Pludselig sætter fortolkningen og inderligheden sig igennem; det er ikke længere jeget på vej, men alting rundt om jeget, som er "under flytning”, hvilket gøĩ læserens oplevelse af digtet centrallyrisk, selvom jegets oplevelse er det modsatte.

Deleuze og Guattaris tredje og konjunktive syntese angår jeget i digtene og henviser til det voluptuøse element som en residual energi. Jeg har allerede været inde på, at man finder et transpositionelt subjekt i Laugesens poesi, hvor subjektet til en vis grad er underlagt stilen. Jeget er hverken kort- eller fastlagt, men noget, der folder sig ind og ud i verden. I Kunsthistorier (s. I6) beskrives det sådan her: "Drømmen er skjult, når man er vågen. Vågen er skjult, når man drømmer. Vågen er jeget $i$ verden. Drøm er verden $i$ jeget”. Vågen er mere end et elegant ordspil. Man kunne sammenligne den eller det med Deleuzes begreb om folden. Folden har to sider, hvor den ene er vendt imod det kaotiske; det formløse, det udenfor, imens den anden er vendt imod dens rolige centrum. Folden sørger for, at verden udenfor mødes som noget, der er i tilblivelse, imens det indenfor er $\mathrm{i}$ venten. Hos Laugesen kaldes det formløse og kaotiske drømmen. Jeget er således ingen fast konstitueret størrelse, men et residu- 
um af en proces, hvor interioritet og bevidsthed skabes i et efterspil. I Katatonien (s. 78) lyder det fx: "desperationen flyder/ ned ad skrænterne/ tyk og brun med en/ kvalmende lugt af mig selv/ skriften er/ udsagn om min tilstedeværelse/ hvor jeg er hvor jeg har været”. Jeget er, hvor jeget har været. Men man kan stadig høre, tale om eller bare sanse, at det er Laugesens skrift eller stil, også selvom jeget optræder som både hund og undulat. Og stilen svækkes ikke med tiden, tværtimod. Stilen forceres, den bryder ud og føder derved sig selv på ny.

Det kunne igen være en grund til, at Laugesen er blevet opdaget så sent. Men det kunne også være sandt, som Lars Bukdahl skriver, at der for Laugesen i 1987 sker en slags humoristisk overtagelse af det poetiske projekt med det traditionelle digterjeg som matrice. ${ }^{77}$ Det skizoide indbygges $i$ jeget, som derved reduceres og frigøres til én af boldene i luften, for nu at bruge et udtryk fra Højholt. For Højholts vedkommende sker der det samme et par år senere med spillet omkring personen og \&-digtene. Men en sådan humoristisk overtagelse beror på, at man i det hele taget har et navn, et omdømme eller en stil (et forfatterskab eller matrice), som kan overtages og sættes i spil. Det er attituderelativisme, ikke effektueret, men affektueret ved hjælp af en metaforisk virkning, som $\mathrm{i}$ årene forinden har været bandlyst; også selvom Højholt allerede i 1983 skriver "Jeg er en metafor". At jeget er en metafor, betyder nemlig ikke, at hverken det eller læseren lades kold. Der sker stadigvæk en projicering af følelser. Et sådan fænomenologisk følelsesfuldt, men fuldt ud kalkuleret felt finder man ikke kun hos Laugesen og Højholt, snarere kan det siges at være én af 1990'ernes revitaliseringer af firserlitteraturen: $\mathrm{Fx}$ at kunne proppe humor og patos ind $i$ samme maskine for at se, hvad der kommer ud af det. At kunne gøre det er i sig selv ikke nyt, det handler snarere om at drage fordel af teksten som en speciel situation, ligesom vitsen, hvor trangen til at fortælle den videre til nogen skal være til stede, før den er vellykket. Vitsen, skriver Freud, ${ }^{8}$ kræver foruden komikkens førsteperson og objektperson én at fortælle den til, dvs. en redjeperson. Når så man lader jeget $\mathrm{i}$ digtene glide fra at være førsteperson til at blive objektper- son, fảr man hele balladen og hele herligheden udstillet. Man kunne som Deleuze i Logique du sens måske endda tale om en fjerde person ental (la "quatrième personne du singulier'). ${ }^{19}$ Men det kræver, at førsteperson (forfatter) og tredjeperson (læser) til en vis grad har en fælles idé om, hvem denne objektperson eller fjerde person ental er og især ikke er; at det $\mathrm{fx}$ er digteren Peter Laugesen med sin hund $\mathrm{i}$ Brabrand eller personen Højholt i bakkerne omkring Hørbylunde. ${ }^{20}$ Men overtagelsen af forfatterskabet er ikke omkostningsfrit, slet ikke når digterjeget bærer sorg som i Kragetæer og pludselig finder sig selv:

Bange som en kanin/ i en tryllekunstners kuffert/ hver gang scenelyset tændes/ for det er altid mig/ der optræder, og publikum/ står smeltende i lyset,/ mens natten tænder ord/ i lange ranker/ af mørke over himlen.

Udstillingen gør jeget sårbart, men desto mere effekt- og affektfuldt i læseren.

$\mathrm{Nu}$ er Dan Turéll slet ikke blevet nævnt i denne forbindelse, men det er jo ham, der har vist sig at være mest fremsynet, hvad ovennævnte angår: Han trodsede den anonymitet, som især Hans-Jørgen Nielsen var med til at indgyde poesien, og invaderede allerede sit forfatterskab i halvfjerdserne. Man bliver trods alt ikke født som en metafor, men man kan måske skrive sig frem til at blive det.

Poul Borum har som Lars Bukdahl travlt med at sætte skel i forfatterskabet og nævner i sit udvalg af Laugesens digte Udtag (Borgen 199I), at det nye sker i 1983. Borum mener, at Laugesen går fra at skrive tekster til at skrive digte, hvilket på sin vis er rigtigt nok. Teksterne bliver mere afinålte og digtagtige, men den gennemgående strøm, som Bukdahl er inde på i sit portræt i Danske digtere $i$ det 2o. århundrede, svigtes aldrig til fordel for autonome og romantiske klodser. Det er til stadighed denne strøm, Laugesen skriver på, om og i. Digtenes jeg hæves kun op i elfenbenstårne for sjov, dvs. de ophæves som oftest af denne strøm. Hvad der mere nøjagtigt sker, er at Laugesen finder en stil, der til stadighed er endnu mere hans egen. Det sker nok ikke så absolut, som hverken Borum eller Bukdahl påstår, 
men gradvist, og det sker stadigvæk for den sags skyld, hvorfor det måske giver mening at påstå, at Laugesen endnu har sit bedste digt til gode $i$ den uafsluttede bog, der er hans forfatterskab, og som han fortsat finder sig selv skrivende i.

\section{Noter}

I. "Det er derfor at teknokraten er diktatorens, datamaskinens og diktaturets naturlige ven, men den revolutionære lever i den forskel, som adskiller den tekniske udvikling og den sociale totalitet, og indskriver dér sin drøm om permanent revolution. Men denne drøm er i sig selv handling, realitet og en reel trussel mod enhver etableret orden; den muliggør det som den drømmer om", Gilles Deleuze: Logique $d u$ sens, Les Éditions de Minuit, Paris I969 s. 64.

2. Gilles Deleuze og Felix Guattari: L'Anti-adipe. Capitalisme et schizophrénie, Les Éditions de Minuit 1972/73 (findes i norsk oversættelse: Anti-Ødipus. Kapitalisme og schizofreni, Oslo 2002).

3.- Kunsthistorier, Borgen I991, s. 24.

4. Jf. Friedrich A. Kittler: Gramophone, Film, Typewriter, Berlin 1986.

5. Kunsthistorier, s. 20.

6. Jf. fx Zenons paradokser og paradokset i det hele taget som også interesserer Deleuze i Logique du sens.

7. Revolutionær og politisk $\mathrm{i}$ den forstand som Jacques Rancière skitserer det i Courts voyages au pays du peuple, Èditions du Seuil 1990, dvs. for os selv at opdage den genkendelige fremmedhed på rejsen, livets flimren, via et uafbrudt nysgerrigt blik, som forårsager en opbrydning af det, der allerede har fundet sammen.

8. Dan Turéll kommenterer i øvrigt i sit portræt af den halvtredsårige Laugesen tillige dette sted i Anarkotika og siger, at poesien leder efter steder, hvor sproget ånder og endnu ikke er underlagt samfundets politisk-kommercielle maskine, hvilket understreger min pointe (Politiken 5. marts, 1992). Portrættet findes desuden i Just a gigolo, 1995 og i Lars Bukdahl (red.): UGH! Et totalskriftportrat af Peter Laugesen, Forlaget Spring 2002.

9. L'Abécédaire de Gilles Deleuze, videooptagelse 1996, “D comme désir".

IO. For en analyse af Deleuze og Guattaris brug af incipit, se Jean-Jacques Lecercle: Deleuze and Language, New York 2002, kap. I. m.m.

II. Denne formel finder man i Milan Kunderas Langsomheden, Gyldendal 1995 .

12. For en uddybende analyse af digtet: Se Anne Borups "Lyrikken slår ikke til når køleskabet starter", om Peter Laugesens digte i Lasninger $i$ dansk litteratur, bind 5, Odense Universitetsforlag 1999.

13.Laugesen siger $i$ et interview, at rim for ham er ustyrligt morsomme i sig selv, hvorfor de ofte ender i bavl. Se "Inspirationen er en mumlende idiot" i månedsbladet Press nr. 85, 1992, s. 22-33.

I4. De Vulgari Eloquentia. A cura di P.V. Mengaldo, i Opere Minori, Tomo II. Milano-Napoli (1979), s. I3.

15. Jf. Agambens artikel "Digtets slutning" i Stefan Iversen (red. m.fl.): Ophold - Giorgio Agambens litteraturfilosofi, Akademisk Forlag, Kbh. 2003.

I6. Deleuze og Guattaris “maskiner" skal nok, som så mange andre af disses termer, snarere forstås som noget, der bliver til mellem begreber og metaforer. Sanselige som metaforer og anvendelige som begreber. "Blandingen" gør, at termerne ofte er nemmere at anvende end at udrede. Det vigtige er først og fremmest, at de skal fungere, men at de fungerer gør dem levende og glatte rent definitorisk.

I7. Ibid. s. 3I.

18. Sigmund Freud: "Der Witz und seine Beziehung zum Unbewussten", Gesammelte Werke, bind 6, Frankfurt am Main 1967.

19. Logique $d u$ sens, s. I66.

20.Se fx digtet side 250 i Nar engle bøvser jazz: "LAUGESEN er ikke lyriker/ skrev de for tredive år siden/ nu skriver de LAUGESEN/ er ikke dramatiker/ og selvfølgelig har de ret/ LAUGESEN er ikke noget som helst/ hvorfor skulle LAUGESEN være noget/ når LAUGESEN kan 